\title{
ALVIN AILEY REPERTORY ENSEMBLE
}

Thursday, March 20, 1980 8:15 p.m., Jesse Auditorium 


\section{Program}

UN-FOUR-GETTABLE

Choreography:

Music:

Composer:

Costumes:

Lighting:

Bride:

Groom:

Father:

Maid:

REFLECTIONS IN D

Choreography:

Music:

Lighting:
Gary De Loatch

Lasanas Priestess

Donald Byrd

Saadia Fine Arts Fashion Inc.

Douglas Drew

Ava Rostant

Eugene Roscoe

Norman Kauahi

Lauren Overby

(First Performance, New York City, 1962)

Alvin Ailey

Duke Ellington ("Reflections in D")

Nicola Cernovitch

Ted Pollen

According to Stanley Dance, Mr. Ellington's biographer: "There is no story. It was just an improvisation in D. Duke always had ideas. It was probably something he had in the back of his mind. It does have structure and character. 'Reflections' suggests more or less what is in it."

CONGO TANGO PALACE (New Production. First Performance, New York City, 1960)

Choreography: Talley Beatty

Music:

Miles Davis \& Gil Evans

Costumes:

Lighting:

(recreated by) Jean Hays

Bil1 Burd

Restaged by Dudley Williams, Masazumi Chaya, Mari Kajiwara 
Cast:

Leslie Woodard, Coc Pelaez, Lauren Overby, Susan Dillon, Eugene Roscoe, Jeffery Ferguson, Hideaki Ryo, Aaron Dugger, Dianne Maroney, Norman Kauahi, George Randolph

First Solo: Jeffery Ferguson

First Duet: George Randolph \& Dianne Maroney

Second Duet: Jeffery Ferguson \& Susan Dillon

Quartet:

Leslie woodard, Coco Pelaez, Hideaki Ryo, Aaron Dugger

An excerpt from "Come and Get the Beauty of It Hot," a long major work by Mr. Beatty. This piece comprises the last section of the ballet. The "Congo Tango Palace" is an imaginery ballroom in Spanish Harlem.

\section{INTERMISSION (Fifteen Minutes)}

ECHOES IN BLUE (New Production. First Performance, New York City, 1975)

Choreography: Milton Myers

Music:

Cos tumes:

Duke Ellington ("Mood Indigo,"* "Harlem"\#)

Lighting:

Normand Maxon

Dancers :

Bill Burd

Ava Rostant, Hideaki Ryo, Ted Pollen, Norman Kauahi, George Randolph, Eugene Roscoe, Regina Hood, Elizabeth Sung, Dianne Maroney

Time: Eve or sunset

Place: Harlem (1930's, 40's)

... and toward the end of the day come echoes; of a longing

to get out, to scream, to release, to dance. Echoes of sorrow, of laughter, of loneliness... Echoes in Blue.

"Mood Indigo," one of Duke Ellington's greatest standards, was written in 1931. When broadcast from the Cotton Club,

*Used with permission of Belwin-Mills Publishing Corp.

\#Used with permission of Tempo Music, Inc. 
it was an immediate sensation. "Harlem" was commissioned of Duke Ellington in 1952 by Arturo Toscanini and was conceived as a concerto grossi for the Ellington band and the symphony. The great Duke described the piece as a panorama of a city within a city. The version used for the ballet is the Duke Ellington orchestra alone.

INTERMISSION (Fifteen minutes)

REVELATIONS (First Performance, New York City, 1960)

Choreography: Alvin Ailey

Music:

Decor and

Costumes:

Traditional

Lighting:

Ves Harper

Nicola Cernovitch

(A11 arrangements by Howard Roberts unless otherwise noted)

"This little light of mine, I'm gonna

let it shine."

This suite explores motivations and emotions of American Negro religious music which, like its heir, the blues, takes many forms - true spirituals with their sustained melodies, sone-sermons, gospel songs and holy blues -- songs of trouble, of love, of deliverance.

"Spirituals sing of woe triumphantly, knowing well that all rivers will be crossed and the Promised land is just beyond the stream. The Spirituals ask no pity for their words ride on the strongest of melodies, the melody of faith. That is why there is joy in their singing, peace in their music, and strength in their soul."

Langston Hughes 